\title{
"The Golden Calf": Noted English Actresses in American Vaudeville, 1904-1916
}

\section{Leigh Woods}

Vaudeville began as a popular American form, with roots in barrooms before audiences of generally unsophisticated tastes. By the time it reached its zenith as a popular form during the first two decades of this century, however, it showed a pronounced taste for foreign attractions rather than for the native ones that earlier had anchored its broad accessibility. In these years just after the turn of the century, notable foreign actors from the English-speaking theatre made their ways into vaudeville, aligning the form, though usually in fleeting and superficial ways, with the glamor and prestige the contemporary stage enjoyed. This pattern bespeaks the willingness to borrow and the permutable profile that have characterized many forms of popular entertainment.

Maurice Barrymore (father to Ethel, Lionel and John) foreshadowed what would become the wave of the future when, in 1897, he became the first important actor to enter vaudeville. His appeal in vaudeville was enhanced by his status, speech, and manners as a British expatriate. The majority of the most important stage stars who followed Barrymore into vaudeville were, in fact, actressesa sign, probably, of the prominence of women among vaudeville audiences. This would make sense in a form known for "continuous" performances, in which one (or more) matinees comprised the standard daily offering. Such repeated and continuous performances, together with some of the newest and best-appointed theatres of the day, helped supply producers with the kind of money necessary to entice stars of the stage into vaudeville.

Four English actresses active in vaudeville in the years following the turn-of-the-century were especially noteworthy. The sequence and manner in which these women appeared in American vaudeville suggest the flavor of the form at its most visible time and some of the changes it underwent in the space of little more than a decade.

\section{$I$}

Jessie Millward was known in her native country as a heroine in melodramas. Wholesome and fresh-faced, she had entered professional acting in 1881, and joined Sir Henry Irving's prestigious Lyceum company in London as an ingenue the following year. Her first tour of the United States came in 1885, and later that year she acted at what would become the citadel of London melodrama, at the Adelphi with William Terriss (Millward, Myself 315-16). Her name became indissolubly linked with Terriss' as her leading man through their appearances in a series of popular melodramas; and this link was forged even more firmly when, in 1897, Terriss died a real death in her arms backstage at the Adelphi, following his stabbing by a crazed fan in one of the earliest instances of violence which can attend modern celebrity (Rowell 77). Her life and acting in melodrama placed her squarely in the matrix of serious attractions vaudeville managers had been cultivating for nearly a decade.

Millward came to vaudeville following the failure of her legitimate play, titled $A$ Clean Slate, in New York in the Fall of 1903 (Millward, Locke Env. 1478, December 3, 1903). ${ }^{1}$ She later recalled that she and the English light comedian, Charles Hawtrey, were "almost the first" actors from the legitimate theatre to enter vaudeville. Her doubts about the wisdom of this venture had been eased by an influential (but unnamed) American lawyer, who assured her of "the desire of the big vaudeville managers for a change in the class of performance, and ... the beauty and comfort of Keith and Procter's [sic] [vaudeville] theatre" (Myself 268). This encouragement was sufficient, apparently, to overcome Millward's quaintly British reservations, as one among a breed of those "legitimate artists [who] were apt to look down upon the music-halls 
as the abode of performing animals and red-nosed singers" (Myself 267).

In late May, 1904, Millward played at two of Keith and Proctor's houses, daily, at the Fifth Avenue and at the Twenty-third Street in New York City. This regimen had her shuttling between the two theatres by cab, once in the afternoon and again at night, for four daily performances of a very brief English spy-drama called "The Queen's Messenger." Not surprisingly, contemporary newspaper accounts had her "more comfortable on the everlasting stage than....in the week of her premiere [in vaudeville]," and had her in vaudeville at all only because of "hard times" (Millward, Locke, June 18, 1904 and July 1904).

In her memoirs, written twenty years later, Millward recalled performing only twice daily, although she may have been conflating her appearances in the same play, and before identifical sets, at the two theatres. Soon after her double run had ended, though, she had told an interviewer that

When the first week of it was over, I caught myself jumping out of bed in the middle of nights and rushing to the door mechanically as if I were going to take another cab to somewhere or other. It was an experience that I certainly shall never go through again. Hereafter, I shall be content to appear in one theatre at a time, giving two performances, of course, each day, but not in places several miles apart (Locke, June 19, 1904).

The $\$ 1000$ per week Millward is reported to have received for her labors in vaudeville (Grau 393) almost certainly credited her four daily performances and frenetic travel between them. She seems also to have moved in a spirit of some generosity and style, later recalling magnanimously that "before and after my performance I was always wildly interested in the other items in the programme, and used to send my maid Lottie down to find out and to report to me what was going on on the stage" (Myself 276). She was pleased also at "the first opportunity I have had in America of showing the serious side of my art and the one for which I think I am best fitted... I am now booked up until nearly Christmas in the vaudeville theatres, and I presume I might as well end out the year that way and postpone my starring tour [in the legitimate] until the season after" (Locke, June 19,1904).

In her early forties, Millward faced not only financial distress but the need as well to alter her range from its locus in the morally-clearcut melodramas that had featured her youthful good looks and innocence. Vaudeville served her interest on both accounts, and helped her to overcome, at least for a time, the professional crises that had befallen her. She was still playing "The Queen's Messenger" in vaudeville at least as late as April, 1905 (Locke, April 28, 1905), and then made her next appearance in London in a comic role a year later, with both her range and her bankroll the fuller, apparently, from her time in vaudeville. This engagement, involving yet another adjustment of her repertoire, may not have gone well either, for in 1906 Vanity Fair had her headed for vaudeville again (October 25, 1906). Nineteen hundred and eight found her in vaudeville once more, compelled there, very likely, by a series of failures in legitimate ventures, although she omits this episode entirely from her memoirs. She tried to recycle "The Queen's Messenger" for this tour, but the play apparently had dated itself during the intervening years, and Variety complained that it was "utterly unconvincing" (Locke, May 2, 1908).

Her last venture into vaudeville came in 19111912 when she toured with her new husband, John Glendenning. She brought a new English play with her this time, called "As a Man Sows" or, when things did not go well, "Reaping the Whirlwind." Variety was less than kind in noting that at Keith's Cincinnati "The audience did not applaud sufficiently to call forth a bow" (October 17, 1911). She and Glendenning played "Reaping the Whirlwind," about a woman forced to poison a worthless man for what Millward would later remember as "entirely excellent reasons," on the far-flung Orpheum circuit of the western states and the Pacific Coast (Myself 289). She would remember this last leg of the tour as an idyll, "more in the nature of prolonged holiday among glorious surroundings than of a workday theatrical tour" (Myself 286-87). The shifting of titles in mid-tour, though, and Millward's subsequent breakdown in New York suggest more stress (Myself 291). Millward's retirement from the stage would follow in 1914, brought jointly by the coming of the First World War, changes in popular taste, her own advancing age, and her husband's death. She is noteworthy, in this chronicle, for her place in bringing a melodrama of more refined variety into American vaudeville that would make it easier for other compatriots, with more glamorous reputations than her own, to follow her.

Lillie Langtry, known as "the Jersey Lily," was renowned less for her acting than for her private life-and in this presented the greatest possible contrast to the exemplary reputation and populist appeal of Jessie Millward. As a young woman, Langtry had been involved in a liaison with the Prince of Wales, eldest son of Queen Victoria, who later lent his name to the Edwardian age as King 


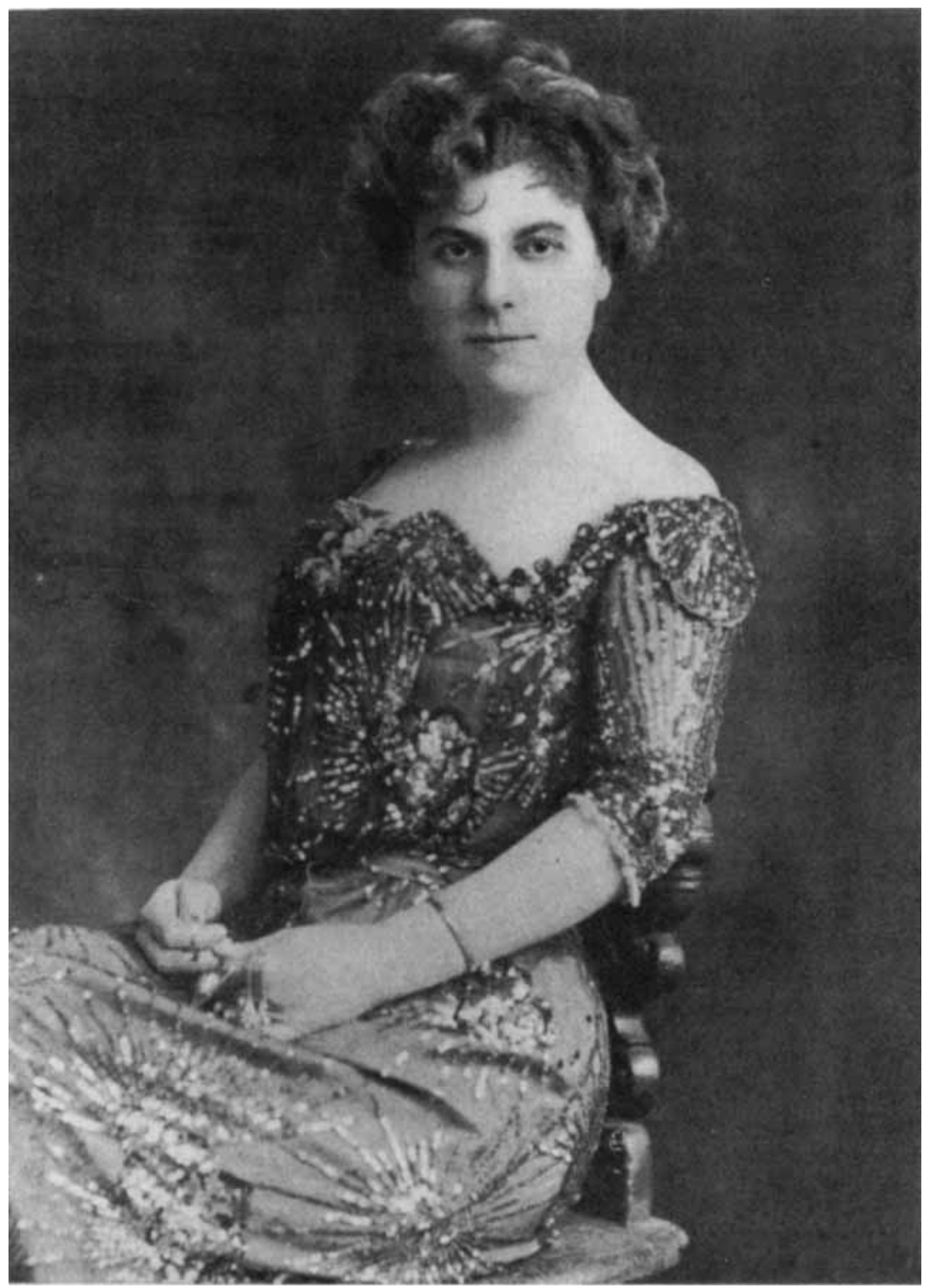

Photo by Sarony, New York.

\section{JESSIE MILLWARD.}

Jessie Millward. Photograph courtesy of the University of Michigan Library.

Edward VII. An actress, then, from her late twenties, Lillie was fifty-four at the time of her first venture into vaudeville. She brought with her the glamor of more than thirty years lived in the public eye, in close conjunction with some of the greatest names in both London and East Coast society in the United States. The New York Morning Telegraph mentioned as part of the preliminary ballyhoo for her entry into vaudeville that, with her father-inlaw's declining health, "we shall have a real English lady on the vaudeville stage" (Langtry, Locke 309, August 1, 1906). She was indeed transformed into
Lady de Bathe, then, midway through her initial tour.

The vaudeville magnates Keith and Proctor got the commercial advantage over competitors by enlisting Lillie as the featured attraction for their grand reopening of their Fifth Avenue house on October 1, 1906. The theatre itself had been refurbished since Millward's appearances there a year and one-half earlier. For Keith and Proctor, Lillie Langtry was an attraction of a different order, too. They furnished her a theatre in which 


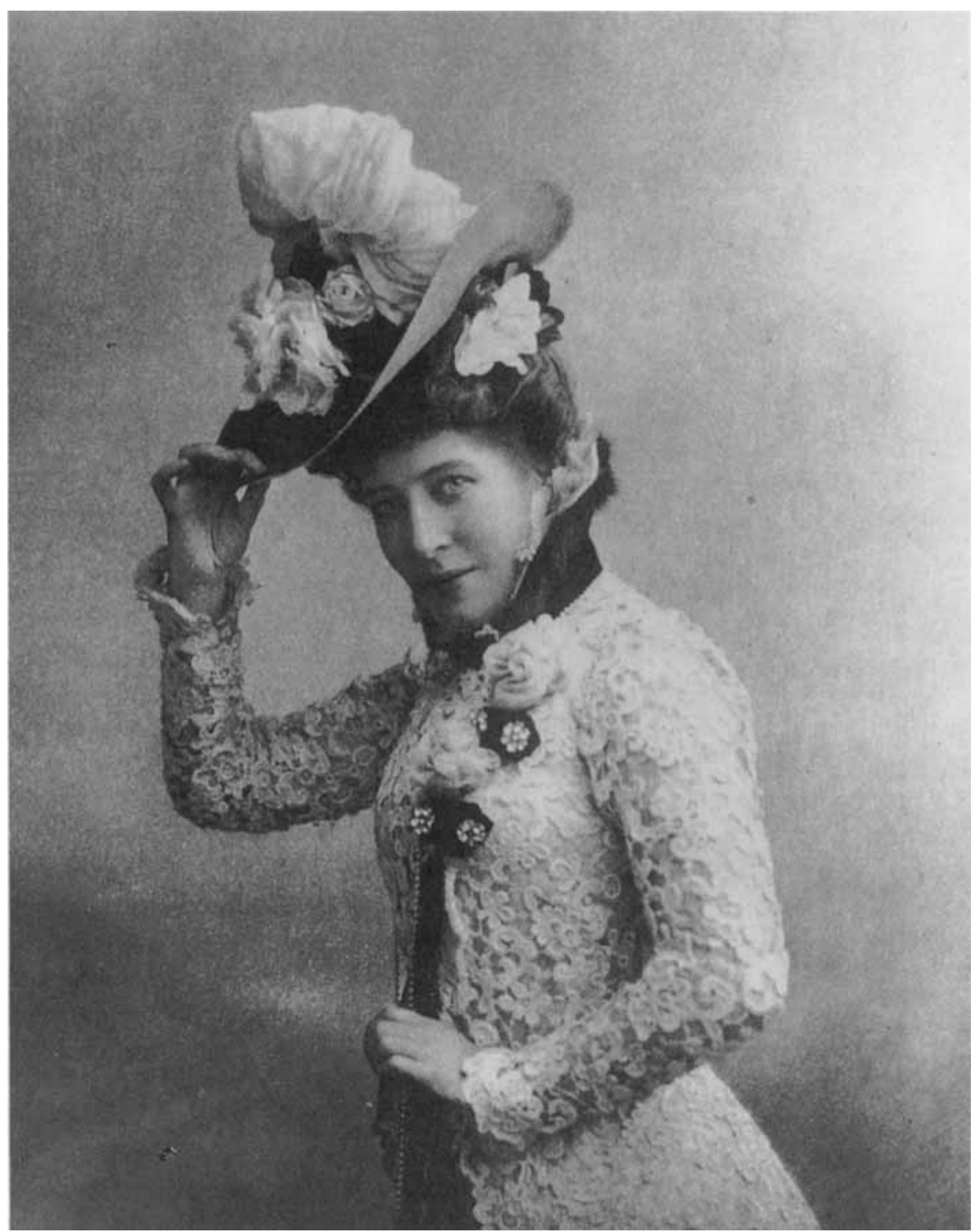

Lillie Langtry. Photograph courtesy of the University of Michigan Library.

Three shades predominate-Parisian gray, chartreuse green and old ivory. The walls are in different shades of green, and the boxes and all the woodwork in ivory and gray. The ceilings are panelled in hues of "crushed rose," blending into cream color. The draperies throughout the auditorium are of a deep Chambertin red and the carpeting a Burgundy red... The new lobby presents a cheerful aspect in its gilt-framed panels of red and absinthe green. There are spacious reception rooms, and they are attractively treated in lavender and cream. In the dome of the theatre are eight panels painted with figures of heroic size, the work of the late Trojetti when he was at his best. (Locke 310, October 1, 1906)

Moreover Keith and Proctor, in order to maximize the impact of Lillie's entry into vaudeville, launched a publicity blitz. They threw a lavish birthday party for her at the theatre in midOctober, and saw to it that stories were circulated concerning her noblesse oblige. One such appeared in the New York Mail, headlined "Mrs. Langtry Books Coon Act." It praised Lillie's patronage of a young performer who had shared a vaudeville bill with her at the Harlem Opera House: "Mrs. Langtry has vowed to take the little black 'cut-up' back to England with her. She watches the 'picks' [for 'pickaninnies'] from the wings at every performance, and at the finish of their specialty the English beauty, in a burst of affectionate enthusiasm, snatches the infantile ink drop and hugs her demonstratively" (October 24, 1906). Lillie's imperial demeanor found further embellishment, according to the New York World Review, in the gown she wore for her playlet of "palest blue velvet embroidered in gold," and designed for her in Paris (Locke, October 2, 1906). ${ }^{2}$ 
Langtry appeared in a play called "Between Nightfall and Light," a chopped down version of $A$ Wife's Peril which she had first acted in the United States in 1894. In a syndicated interview that appeared in the Chicago Record, she sought to inspire a greater deference than the press had been accustomed to granting vaudeville attractions: "For heaven's sake, please don't ever refer to my playlet as a sketch! That sounds too vaudevillainous for anything. I could never stand it. I call my endeavor 'A tabloid tragedy.' The name of the tabloid tragedy is 'Twixt the Nightfall and the Light,' a line from [Robert] Browning"' (Locke, September 30, 1906). It is consistent with other aspects of her grandiosity that she made the title even more literate than it was as listed on her vaudeville programs. In the play, Lillie acted a young wife confronted by her husband's best friend, who tells her that his own wife is her husband's lover, and then demands either that she elope with him or consent to her husband's death at his hands. Once the wife has absorbed this information, she decides she loves her husband still and, putting on articles of his clothing, goes into her garden where the former best friend, mistaking her for her husband, mortally wounds her with a pistol. She has a death-scene, and expires. Lillie, of course, took care through her change of costume not to soil her French gown in the process. There would have been no time to clean it between an afternoon's performance in vaudeville and an evening's.

For her second vaudeville tour, in 1912-13, Lillie played still in "Between Nightfall," recycled under a different title as "The Test," but alternated it with two other pieces dealing with the contemporary women's suffrage movement. She may have been striving in this to update her image and to appeal to topical interests. The experiment was not a success. Her "Helping the Cause" was, in fact, a spoof of the women's rights movement, and was not warmly greeted by vaudeville audiences evidently hungry to see Lillie in more glamorous roles. As the title character in "Mrs. Justice Drake," Lillie played a woman judge involved in, according to one review, a sequence of "prankish situations arising from the regime of the suffragettes" (Locke, February 18, 1913). This piece seems to have gone better, and Lillie played it through the balance of the western part of her tour and into Canada.

For her final tour of vaudeville, beginning in the Fall of 1915 following her failure in a new fulllength play in the South, Lillie found two new serious pieces to act, called "Ashes" and "The Eleventh Hour." Both of these plays returned her closer to racy type, in domestic triangles that involve a wife's decision to love and stay with her husband after her bouts of dalliance. The eastern part of this tour found her supported by Lionel Atwill, later famous in films, as her lover (Locke, New York Telegraph, December 1, 1915). Atwill was then thirty years old, playing his romantic role opposite Lillie's sixty-three years. On the Orpheum circuit, Lillie settled on a then little-known American, Alfred Lunt, to provide her professional support. Lunt was at the time only twenty-four. According to his memoirs, an affair grew up between himself and Lillie, and he remembered her, years later, "with the bluest eyes I have ever seen." (Brown 73). Vaudeville also generated moments of the ridiculous as well as the sublime: while playing at the Columbia Theatre in St. Louis on this tour, Lillie shared a bill with Jack Benny who, at the time, worked wordlessly with a partner named Woods, offering "ten minutes of syncopation" on the violin (Locke, December 1916).

Langtry's marmoreal beauty, sophistication, and cachet lent vaudeville an aura it had not previously achieved. It is little wonder that she received $\$ 2500$ weekly for her first tour in 1906 , at that time the highest salary ever paid to a headliner touring in vaudeville. Although she was not so well paid for her final tours, she seems, nevertheless, to have been offered enough money to subject herself again to the rigors of touring and twice-daily performances with which she had first grown familiar in 1906.

Her first appearance in vaudeville seems also to have paved the way for her tour of English provincial music halls in 1911, in another shortened version of an earlier theatrical success, Sydney Grundy's The Degenerates (Dudley 204). Lillie apparently felt freer to take the plunge into a popular form in America than she did in her native country, where the stigma appears to have been greater, and over a longer time, and the pay less substantial. In any case, her autobiography leaves out her engagements in vaudeville and music halls entirely, and spends only about one-sixth of its length on the legitimate part of her stage career (The Days I Knew 162-211). Clearly, her attraction to vaudeville audiences, like her attraction for patrons of legitimate theatres, lay in more in her social profile and then it did in her acting.

Mrs. Patrick Campbell created a sensation of a different sort in 1893, around her portrayal of Paula, the guilt-ridden title character of Pinero's The Second Mrs. Tanqueray. Although she would later play Juliet, Ophelia, and Lady Macbeth, her career was based around a more contemporary sort of dangerous love, including the title role in The 
Notorious Mrs. Ebbsmith, another of Pinero's works, as Lady Hamilton in Nelson's Enchantress by Risden Home, and as the temptress Fedora in Sardou's play of the same name written originally for Sarah Bernhardt.

Certain elements of her personal life further embellished the notoriety surrounding her repertoire, although not to the same degree as was the case with Lillie Langtry. In her memoirs, she wrote that she came to the United States in 1910 in order to "get away from England-and gossip" (Campbell, My Life 309) She was, at the time, romantically involved with George CornwallisWest, while West was still married to the former Lady Randolph Churchill. Campbell had also declared bankruptcy only two years previously. In her negotiations with the vaudeville magnate, $\mathbf{E}$. F. Albee, Mrs. Pat asked for $£ 500$ weekly and Albee met her demand-to the tune of $\$ 2500$ a week in those days when the pound was faring better against American currency-after having seen her try out a play called "Expiation" before setting her opening for the Colonial in New York City on Valentine's Day, 1910. Her asking price may well have been informed by her knowledge of Langtry's huge salary three and one-half years prior.

In "Expiation" Mrs. Pat played a woman forced to pretend love and commit murder against a backdrop of political intrigue in Russia. She did not quite last out the ten weeks in vaudeville she had contracted for. She made it to houses in Brooklyn, Philadelphia, Chicago, Indianapolis, Cincinnati, and Boston, before abandoning her tour, due, she claimed, to fatigue. Years later, she would complain of the strain she felt from "those two performances of Expiation! I had to kill a man twice a day and shriek - and it had to be done from the heart-the Americans see through "bluff' " (My Life).

After a brief rest in Canada, she took up her tour again in Chicago in a short play her son Alan had written, called "The Ambassador's Wife." Mrs. Pat would remember her son's play in her memoirs later as "quite a success in its way" (My Life); but this remark suggests either her indifference to or ignorance of general reaction to the play-further enlarged in her case, perhaps, by her maternal loyalty after the subsequent death of Alan following his enlistment in the British army during the First World War. In any case, Mrs. Pat was politic when, to the Chicago Journal during the first leg of her tour, she spoke of "being prouder of my success in vaudeville than I can tell you. After all, it is the real test of the artist. In legitimate you have three or four acts and a couple of hours in which to prove your mettle... Here it is different. You've got to strike the minute you make your appearance" (Campbell, Locke 98, February 23, 1910).

In her memoirs, however, she would write in quite another tone about her initial warning, offered to Albee when she was signing on, that she "would never be able to play twice a day and travel on Sundays for any length of time" (My Life 309). She seems to have exaggerated the length of her sabbatical in Canada to ten weeks-it was more like ten days (Peters 498)-and she lends her account of the breakdown preceding it a highly dramatic flavoring:

One day-I forget in which town-it was time to get up and think about the morning performance. I found I was unable to make any effort to move. My maid rang the telephone for the Hotel doctor-I tried to speak; it was impossible, I could only cry. 'No more acting; away to Canada, to St. Agathe des Montes, and stay there until your nerves are mended,' said the doctor (My Life 310).

There were no morning performances in the class of vaudeville houses in which Mrs. Pat appeared, and she must have felt oppressed-to the point of either misrecollection or exaggeration-by unremitting travel, continual changes of the bills, daily matinees, and constant repetition of the same slight piece.

In her recollections, Mrs. Pat adopted the same tone of passivity and helplessness as in her version of her meeting with Albee to contract her tour in the first place. Then, she remembered, after her initial cordial exchange with Albee himself who, in his hearty and, to Mrs. Pat's eyes, rather crude American way took pains to make her feel that she was "all right... Some other men came into the room... and they consulted together. Eventually it was decided that I should play for a week outside New York, and if I proved worth it, they would engage me at the $£ 500$ a week for ten weeks. I played and they were satisfied" (My Life 310). Clearly, Mrs. Pat understood her role in this exchange as that of a monetary and sexual commodity.

On the other hand, Mrs. Pat was never known for her timidity. It is interesting, in this light, that in her autobiography she put herself consistently in the role of the one being acted upon-much as, in "Expiation," she remembers having "had to kill a man." The tax on her glamor-her "expiation," after a fashion-came through a kind of suffering enacted in the United States in a play involving feigned love and in a form of entertainment she found brutal and mechanical. And yet, the year after her failure to complete her tour the New York 


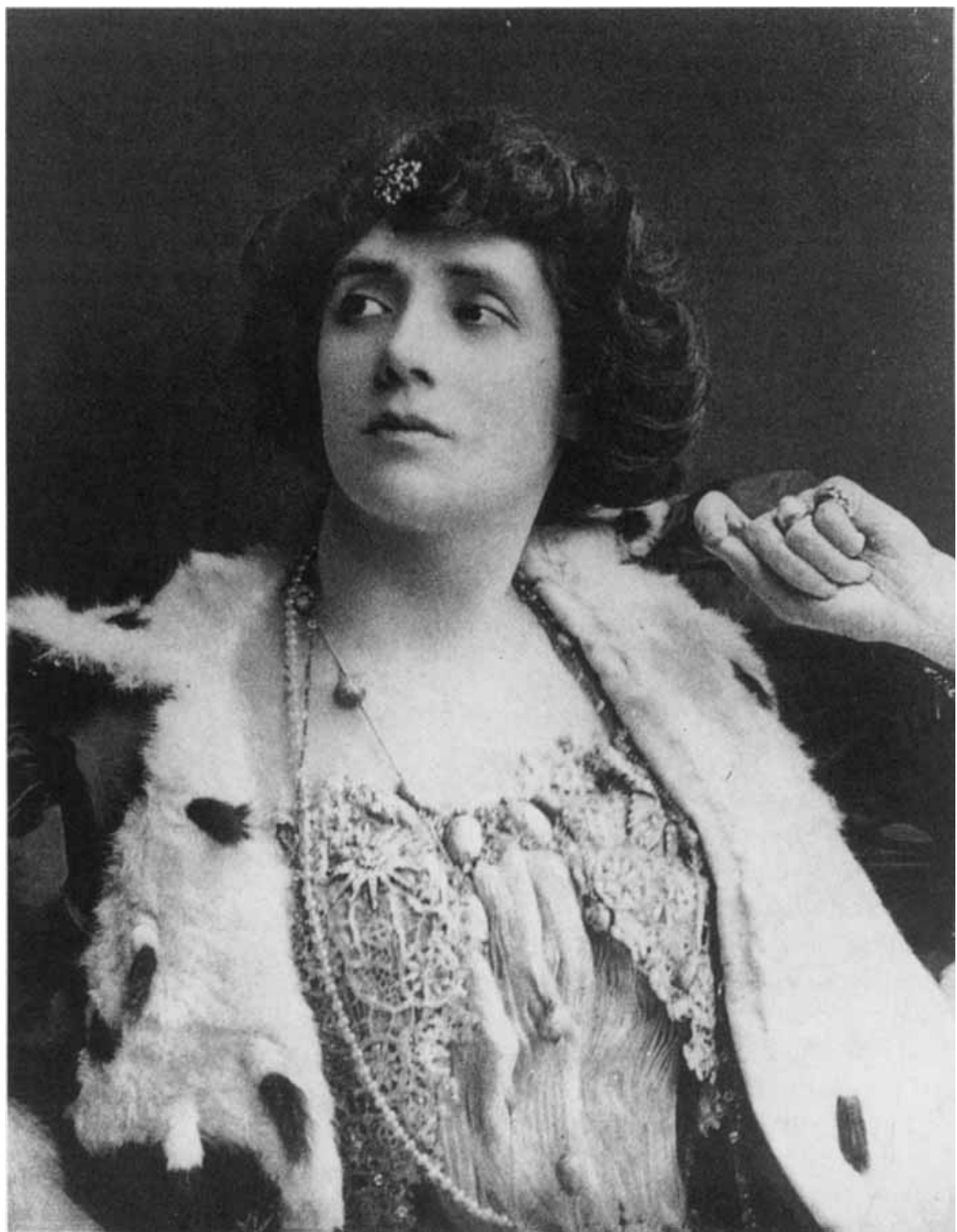

Mrs. Patrick Campbell. Photograph courtesy of the University of Michigan Library.

Dramatic News had her considering another venture into vaudeville (January 28, 1911). As late as 1926 , the New York Telegraph announced her ready to tour in vaudeville again, in a playlet that was to have been directed by Albee himself (Campbell, Envelope 6490, December 26, 1926). Her public "expiation" made for lucrative business indeed, and vaudeville seems to have offered her, like Lillie Langtry, some of the more attractive rewards for her skill and reputation.

Vaudeville audiences, for their part, seem to have shared Mrs. Pat's enthusiasm for the "lovely frock" she had brought with her to America in anticipation of a lucrative engagement there $(M y$ Life 309). The New York Sun praised her "shimmering black and silver frock" in "Expia- tion" (February 16, 1910), and Variety went on at greater length about her "wonderful gown of black satin, over which is a coat of cut steel to the knees. The skirt is banded with an edge of steel, the coat having a border of sable fur" (February 19, 1910). Like Lillie Langtry, Mrs. Pat seems to have perfected an imperious air with journalists and theatre functionaries. One press agent showed his awe in remarks to the Chicago Tribune: "We have to handle these stars from the legitimate careful like. Now, here's Mrs. Campbell, probably the greatest woman on the stage. She doesn't understand vaudeville... She's used to being the whole thing... if she wants quiet and nobody in the house when she rehearses, then you bet that's the way it's going to be" (May 23, 1910). 
Mrs. Pat later followed Langtry into English music halls, by only a few months, in 1911. She then diverged from Lillie by re-establishing herself in the legitimate theatre following her vaudeville and music hall engagements, when she created Eliza Doolittle in Pygmalion for George Bernard Shaw in 1914. Thus she alone, among all the English female stars who entered vaudeville, mounted a great success which transcended the blight which engagements in the degraded popular form was believed to carry over into the legitimate.

Olga Nethersole became associated, even more than Mrs. Patrick Campbell, with a single roleas Fanny Legrand in a notorious play adapted by Clyde Fitch from a French novel by Daudet, called Sapho. Her appearance in the play in New York City in 1900 had resulted in her arrest on charges of public indecency, in a spectacular show trial, and in her vindication. This was followed by a lengthy and lucrative run in the vehicle that would shape the rest of her career and carry her, finally, into vaudeville.

Nethersole was, in some ways, a pocket version of Mrs. Patrick Campbell, following her into the two raciest of Pinero's works, The Second Mrs. Tanqueray and The Notorious Mrs. Ebbsmith. Indeed, it was Mrs. Tanqueray she fell back on when Sapho was banned in New York and she needed income to support the cost of the city's legal action against her. She, like Mrs. Pat and Lillie Langtry, was associated with characters of bold and unconventional behavior, having also played Camille, Carmen and the Latin temptress Lola Montez over the years (Reilly, "Fallen Woman" 106). Indeed, one of the trademarks of her style came in the "Nethersole Kiss," which made itself a recurrent feature not only in her acting, but in the newspaper accounts of it as well ("Fallen Woman" 108-09). It was this notoriety, then, and that which attached still to Sapho that precipitated her debut in vaudeville at the Palace Theatre, New York, then open for only a few months, in early October, 1913.

$V$ ariety showed uncharacteristic enthusiasm for a legitimate actress in vaudeville in praising Olga and her playlet, a 27-minute version of the third act of the four act Sapho. It also praised the set and the lighting, which, in contrast to the perfunctory scenic effects then common in vaudeville, "looked like a real interior, a real dining room in a country home in France. The transition from daylight to sunset was accomplished as never before in a vaudeville theatre" (Nethersole, Locke 364, October 10, 1913). In choosing Act III of the original for vaudeville, Nethersole was seeking to regenerate the sensation it had generated during her first run of the piece some fourteen years before.

She also chose that part of the play in which conventional morality reared its head most vigorously. In this act, Fanny's husband, Jean, begins to feel trapped and isolated in his marriage, and to miss his days as a Parisian roué. Fanny counters by trying to persuade him to adopt a child. At first he embraces this idea, but then denounces Fanny for proposing it when he discovers that the child she has in mind is in fact her illegitimate son by a previous lover. They argue, he flings out of the house, and she resolves to care for the child by herself. Curtain!

In the full-length version, the audience had been exposed to Fanny at her first entrance dressed as the goddess Venus. The first act ended in a steamy encounter that involved Jean's carrying her up a staircase to her bedroom ("Fallen Woman" 115). In the truncated and sanitized vaudeville version, it was only the savor of shock and sensation that remained, in the title itself and in Nethersole's association with the legendary poetess of Lesbos. The play as a whole had depicted pleasure followed by its penalties: the vaudeville version showed only the penalties and obligations which followed from sensuality indulged.

On her vaudeville tour, Nethersole alternated Sapho with "The Last Scene of the Play," as a bride who discovers on her wedding night that her husband has murdered his former wife and is being tracked by detectives. Nethersole played this piece for the first time at Keith's Philadelphia, in what the Philadelphia Times said was a most unusual occurrence, suggesting some risk for a star of her magnitude in a form which demanded speed, polish, and assurance (October 24, 1913). The other English actresses had played almost exclusively in pieces that they had acted before, or in ones that had been proven by other actors. In any case, after playing the remainder of her Keith tour of the East Coast by alternating in these two plays, she then ventured onto the far-flung Orpheum tour of the Western United States and Canada. She, unlike Mrs. Pat, stayed her tour through to its contracted end.

In Boston, where she had headed after playing the Palace, she shared a bill with the Three Keatons-including future film star Buster, then an acrobat-and with Sophie Tucker, who as "The Last of the Red Hot Mamas" betokened something of the franker and, apparently, less glamorous native sensuality to which the imported Olga offered vampish contrast (Boston Herald, October 28, 1913). The next month, she won a suit for breach of contract against Shuberts, which had been 


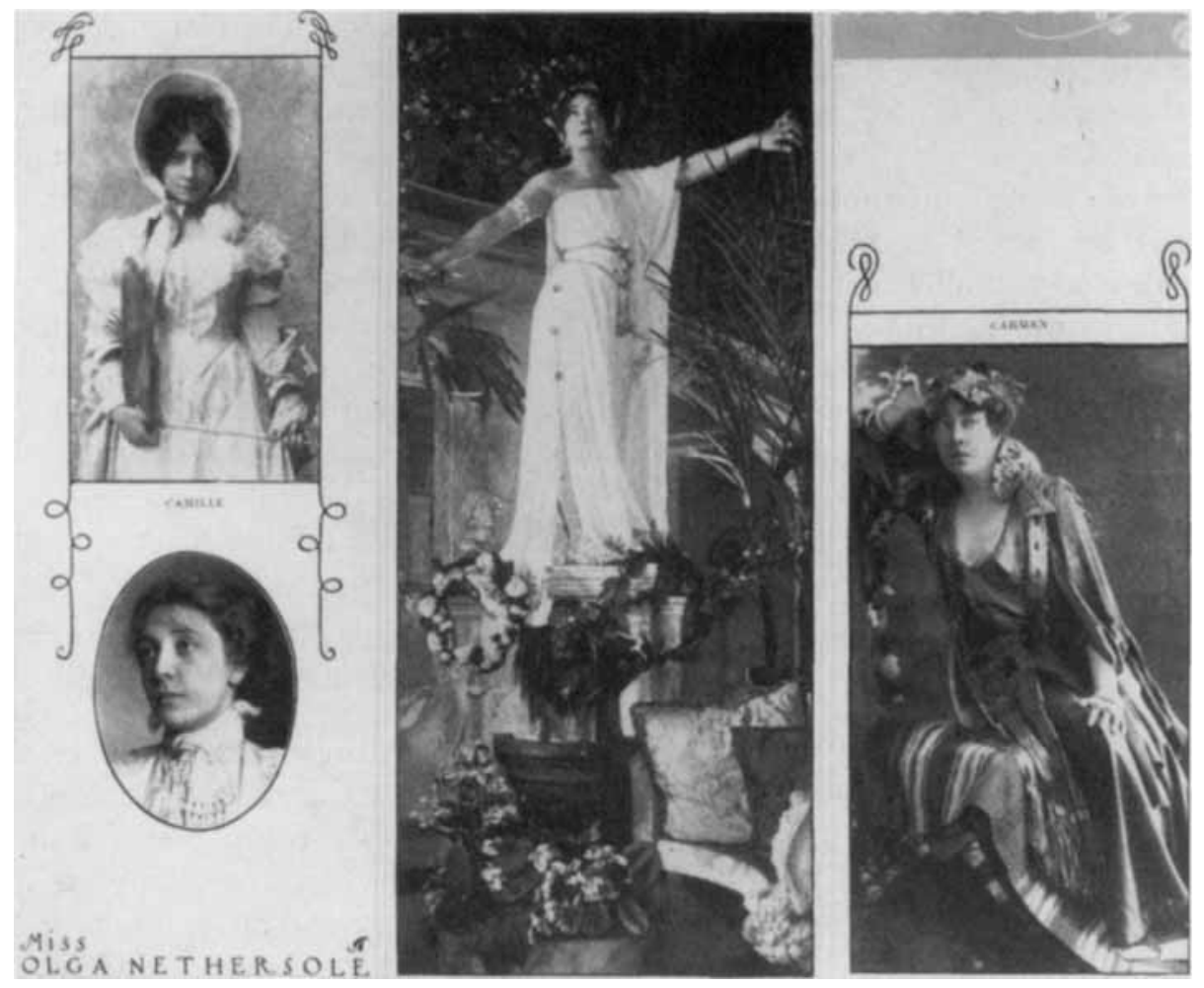

Olga Nethersole. Photograph courtesy of the University of Michigan Library.

languishing in court for many years. Her part of the judgment came to $\$ 32,000$ (Locke 364), and this may have eased her way into the long retirement that she would then enjoy after her tour of vaudeville ended-save for a single performance at a benefit in London in 1923. She seems never to have been able to escape her professional association with Sapho, nor, indeed, to have wanted to. She may have found herself chained to it in a way that parallels the parasitic relationship the Irish immigrant James O'Neill, father to the great American playwright, felt finally to his own staple, The Count of Monte Cristo-in which he had made his last appearance, also in vaudeville and acting with his sons, only two years previously (Sheaffer 214-21).

A certain grandeur in Nethersole's style bodied forth not merely in gowns and furs ("Fallen Woman" 106), but in the manner in which she took her curtain calls. The New York American had her taking no fewer than fourteen of them following her first playing of Sapho in vaudeville (October 7,1913 ). Variety took her to task for these numerous "unnatural Bernhardt bows" (October 10, 1913), which on the legitimate stage had been supplemented by nervous prostration and fainting spells ("Fallen Woman" 115) and may have been embellished in something of the same way in vaudeville, too. Something of the mannered figures in William Winter's image of her style, too, characterized as he saw it by "an unsympathetic temperament, and... always artificial" (316). These qualities, of course, were not typical of the English actresses generally. It is also likely that such features would have prevented an American actress from reaching the stature, either on the legitimate stage or in vaudeville, that Olga Nethersole was able to achieve.

\section{II}

In the year after Jessie Millward's first foray into vaudeville, Hartley Davis would write of the vaudeville managers' use of the term "Two dollar stars" to describe the category of stage actors sufficiently eminent to justify raising the traditionally low prices charged in even the finest vaudeville theatres (236). It was these elevated ticket prices that helped managers to offer stars salaries in excess of what they were accustomed to getting on the legitimate stage. Such salaries, as we have just seen, often enticed actresses who found themselves at points of crisis, whose appeal in the legitimate theatres had waned, at least momentarily, or who felt themselves nearing the ends of their careers. In one way or another Jessie Millward, Lillie Langtry, Mrs. Patrick Campbell, and Olga Nethersole turned from times of doubt, inactivity, and reflection toward quicker, shorter, multiple 
turns before vaudeville's larger and more restless audiences. To the extent that they benefitted from vaudeville, they suffered from it also in its relentless exposure of qualities revealed as inappropriate to the form, or dilapidated.

They also gained from a situation in which they could market their appeal as the heirs to a long and distinguished stage tradition, in a country desperately in need of artistic traditions. At the same time, though, vaudeville featured them-all except Jessie Millward-in racy material of a sort then unfamiliar to vaudeville audiences, and which flouted the moral traditions which those audiences, to a great degree, held in common. English actresses seem to have been able to essay sensational material in vaudeville precisely because they had a more august and formidable stage tradition to legitimize their efforts-and because they had made their fame by playing such material in the first place.

Vaudeville brought English actresses of note into its midst, then, to measure, the tradition from which they sprang, to praise it, and then also, paradoxically, to criticize the divergences it permitted from American norms of behavior. In vaudeville, as in many other popular and legitimate entertainments, we see in this the ambivalences left by colonialism in its economic and cultural aftershocks. Many members of American audiences, both in vaudeville and in legitimate theatres, showed a kind of fealty-and at the same time, distaste-for English culture in the persons of the several actresses who brought it with them into vaudeville. Such responses have waned somewhat, but they can be seen to endure among American stage and motion picture audiences to the present day.

If vaudeville was a venal business, so, too, was a legitimate theatre which insisted always on distinguishing itself from its bastard cousin. There is a singular irony in the way the more "popular" form subverted its very nature by raising its prices in order to draw stars from the stage into its embrace. Vaudeville generated more money for itself in the short run, but in the longer run created a spiralling vogue for novelties and sensations which it could not satisfy indefinitely. By rewarding reputation, notoriety, and glamor borrowed from foreign and legitimate sources, vaudeville left itself open to any form which could outbid it for the services of notable actors, could more successfully market the commodity "fame," or could more entirely recast personal appearance. Such capacities then came, of course, with the advent of feature films. Charlie Chaplin's first great successes in motion pictures fell in 1914, and it is not coincidental that this development marked the virtual end of the access of Chaplin's more statuesque and dignified countrywomen into vaudeville. Vaudeville responded to this, in turn, by expanding the role of films-and of stage stars in them-within its own bills. But it was, from this time, fighting a losing battle against a form of entertainment better able to address a much larger audience.

The odd juxtapositions suggested by actors of note featured in twenty- or thirty-minute segments on bills with acrobats, jugglers, and animal acts also anticipated-in television-an even nearer cousin to vaudeville, with television's "postmodern" affinity for the disjunct, the self-referential, and the incongruous. Lillie Langtry justified her engagement in vaudeville by reminded an interviewer that, "I worship the golden calf, and there is money in vaudeville" (Golden 70). The irony of Lillie's remark lies in the fact that the golden calf was also herself. She, together with others of her compatriots seem to have partly recognized their complicity in the processes by which they found praise and prosperity, and, at the same time, exploitation and harsh moral judgements. It is ironic, too, that vaudeville would serve the same sacrificial function for films and television, which first melted it down with capital and then cannibalized it.

\section{Notes}

${ }^{1}$ All newspaper references here have been drawn from the Robinson Locke scrapbooks and clippings, and in the case of Mrs. Patrick Campbell, from another element as well of the Billy Rose Theatre Collection of the New York Public Library at Lincoln Center. I have included further information concerning the Locke Collection or other catalogue information in the first newspaper citation for each of the four actresses. Thereafter, I have included volume, envelope, or catalogue numbers only when these have come from another volume or part of the Collection. Many items from the Locke Collection are identified only by date, and lack the newspaper of source. When the name of the newspaper is clear from Locke's clippings, I have listed this information together with the date.

2Langtry's designer is identified as "Drecoll of Paris" in a Colonial Theatre program from the week of November 19, 1906, at the Firestone Library, Princeton University.

\section{Works Cited}

Brown, Jared. The Fabulous Lunts: A Biography of Alfred Lunt and Lynn Fontanne. New York: Atheneum, 1986.

Campbell, Mrs. Patrick (Beatrice Stella Cornwallis-West). $M y$ Life and Some Letters. 1922. New York: Benjamin Blom, 1969. 
Robinson Locke Scrapbooks. Volumes 98 and 99 . Billy Rose Theatre Collection of the New York Public Library at Lincoln Center.

Envelope MWEZ + n.c. 6490 .

Davis, Hartley. "In Vaudeville." Everybody's Magazine 13 (August 1905): 231-40.

Dent, Alan. Mrs. Patrick Campbell. London: Museum Press Limited, 1961.

Dudley, Ernest. The Gilded Lily: The Life and Loves of the Fabulous Lillie Langtry. London: Oldhams Press Limited, 1958.

Golden, Sylvia B. "The Romance of the Jersey Lily." Theatre 52: 357 (December 1930): 39-40, 69-70.

Grau, Robert. "The Growth of Vaudeville." Overland Monthly 54 (October 1914): 392-96.

Langtry, Lillie (Lady de Bathe). The Days I Knew. New York: George H. Doran Company, 1925.

Robinson Locke Scrapbooks. Volumes 309 and 310. Billy Rose Theatre Collection of the New York Public Library at Lincoln Center.

"Nethersole, Olga." Robinson Locke Scrapbooks. Volume 364. Billy Rose Theatre Collection of the New York Public
Library at Lincoln Center.

Peters, Margot. Mrs. Pat: The Life of Mrs. Patrick Campbell. New York: Alfred A. Knopf, 1984.

Reilly, Joy Harriman. "From Wicked Woman of the Stage to New Woman: The Career of Olga Nethersole (18701951)." Diss. Ohio State University, 1984.

"A Forgotten 'Fallen Woman'." In When They Weren't Doing Shakespeare: Essays on Nineteenth Century British; and American Theatre. Eds. Judith L. Fisher and Stephen Watt. Athens: U of Georgia P, 1989. 106-120.

Rowell, George. William Terriss and Richard Prince: Two Characters in an Adelphi Melodrama. London: The Society for Theatre Research, 1987.

Sheaffer, Louis. O'Neill, Son and Playwright. Boston: Little, Brown and Company, 1968.

Winter, William. "The Sacred Labors of Olga Nethersole." In The Wallet of Time. Volume II. New York: Moffat, Yard, 1913. 309-322.

Leigh Woods is Head of Theatre Studies, University of Michigan, Ann Arbor, MI 48109. 